\title{
Brown midrib corn silage fed during the peripartal period increased intake and resulted in a persistent increase in milk solids yield of Holstein cows
}

\author{
W. C. Stone, ${ }^{\star 1}$ L. E. Chase, $†$ T. R. Overton, $†$ and K. E. Nestorł \\ *Diamond V, Cedar Rapids, IA 52404 \\ †Department of Animal Science, Cornell University, Ithaca, NY 14853 \\ $\ddagger$ Mycogen Seeds, Wooster, OH 44691
}

\section{ABSTRACT}

The objective of this study was to evaluate transition cow performance when brown midrib corn silage (BMRCS; Mycogen F2F444) was included in the diet during the transition period, and to determine if any production response occurring during the first $3 \mathrm{wk}$ of lactation would persist from wk 4 to 15 when a common diet was fed. Seventy Holstein dairy cows were blocked by parity (either second or third and greater) and calving date and randomly assigned to the CCS (a mixture of varieties of conventional corn silage) or BMRCS treatment. Diets were formulated with the objective of keeping all ration parameters the same, with the exception of neutral detergent fiber digestibility. Neutral detergent fiber digestibility values $(30 \mathrm{~h})$ for CCS and BMRCS averaged 56.8 and $73.8 \%$, respectively. Prepartum rations contained $47 \%$ corn silage, $18 \%$ wheat straw, $7 \%$ alfalfa haylage, and $28 \%$ concentrate, and averaged $45 \%$ neutral detergent fiber (DM basis). Postpartum rations contained $40 \%$ corn silage, $15 \%$ alfalfa haylage, $1 \%$ straw, and $44 \%$ concentrate. Milk weights $(3 \times / \mathrm{d})$ and dry matter intake were recorded daily, and milk composition was measured weekly. Cows fed BMRCS had higher dry matter intake during the 2 -wk period before calving (14.3 vs. $13.2 \mathrm{~kg} / \mathrm{d}$ ) and the 3 -wk period after calving (20.1 vs. $18.1 \mathrm{~kg} / \mathrm{d}$ ) than did cows fed CCS. Yields of milk, solids, and lactose were increased, whereas a trend was observed for a reduction in somatic cell counts and linear scores in the postpartum period for cows receiving BMRCS during the transition. A significant carryover effect of BMRCS was observed on production from wk 4 to 15 when the common diet was fed, with yields of protein (1.36 vs. $1.30 \mathrm{~kg} / \mathrm{d})$, lactose $(2.24$ vs. $2.12 \mathrm{~kg} / \mathrm{d})$, and solids $(5.82$ vs. $5.51 \mathrm{~kg} / \mathrm{d})$ increasing significantly, and yields of fat-corrected milk, energy-corrected milk, and fat tending to increase during this period for cows that had been fed BMRCS. The

Received March 12, 2012.

Accepted July 8, 2012.

${ }^{1}$ Corresponding author: bstone@diamondv.com

increased intakes during the last $2 \mathrm{wk}$ of the prepartum period in the BMRCS treatment were likely because of a reduction in fill, whereas the increased intakes in the postpartum period in cows fed the BMRCS were either because of the higher intakes during the prepartum period or because of a reduction in fill limitations in the postpartum period. The carryover response in wk 4 to 15 may have resulted from cows that received BMRCS during the transition period being in a more positive nutrient balance than cows fed CCS. The results of this study indicate the importance that digestible NDF can have in transition diets and the long-term production responses that can occur when intake is increased in the transition period.

Key words: brown midrib, peripartal, transition dairy cow

\section{INTRODUCTION}

Brown midrib corn silage (BMRCS) has lower lignin levels than conventional corn silage (CCS), resulting in a consistent improvement in NDF digestibility in vitro (Cherney et al., 1991; Allen, 2000). This typically results in an improvement in DMI and milk production (Oba and Allen, 1999a; Ebling and Kung, 2004). The improvement in digestibility in vivo, however, is usually considerably less than the in vitro estimates (Allen, 2000). Oba and Allen (2000) evaluated the ruminal and total tract NDF digestibility values of BMRCS and CCS in cows fed low and high NDF levels. Even though the BMRCS had a 30-h in vitro digestibility value 9.4 percentage units higher than that of CCS, no differences were observed between corn silage types in ruminal or total tract digestibility. Lactating cows fed forages with similar NDF levels but different digestibility values have produced more milk and had higher DMI when fed the more digestible forages (Oba and Allen, 1999b). The faster ruminal passage rate of the NDF from BMRCS (Oba and Allen, 2000) has allowed cows that are more limited by reticuloruminal (RR) fill to consume more feed, leading to increased production (Oba and Allen, 1999b). It is interesting 
that despite the numerous lactating cow trials with BMRCS, a paucity of studies exist that involve its use in transition dairy cows. Santos et al. (2001) fed 112 Holstein cows CCS or BMRCS from 3 wk prepartum until 4 wk postpartum. All cows were fed a common diet from wk 5 to 14 . The authors reported that cows fed the BMRCS produced more milk and FCM for the first $4 \mathrm{wk}$ of the study when fed the BMRCS, and they continued to produce more milk for the next $10 \mathrm{wk}$ when all cows were fed the same lactating cow ration with CCS (Santos et al., 2001).

On commercial dairies, cows are often moved to a precalving group approximately 3 to 4 wk before the expected parturition date, and after parturition, they are moved to a postcalving group for approximately an additional $3 \mathrm{wk}$. This period is commonly referred to as the transition period. Corn silage is the predominant forage fed on many dairies. This study was designed so that the length of time that cows were fed the experimental diets ( 3 wk before and after parturition) and the relative amount of corn silage included in the diets were similar to what commonly occurs on commercial dairies.

The objective of this study was to evaluate transition cow performance when BMRCS was included in the diet during the transition period, and to determine if any production response occurring during the first $3 \mathrm{wk}$ of lactation when BMRCS was being fed would carry over after all cows were fed CCS.

\section{MATERIALS AND METHODS}

\section{Experimental Design and Treatments}

The study was conducted from July 2006 until February 2007. The study and all experimental procedures were approved by the Cornell University Institutional Animal Care and Use Committee. Seventy Holstein dairy cows were blocked by parity (either second or third and greater) and calving date and randomly assigned to CCS or BMRCS treatments. Three cows (1 from CCS and 2 from BMRCS) were dropped from the trial near parturition because of problems not associated with the study (udder with poor suspensory ligaments, chronic foot problems, Staphylococcus aureus mastitis). Data from cows with mastitis during the first $6 \mathrm{wk}$ of lactation were included in the statistical analysis, whereas data generated during a mastitis event during wk 7 to 15 were excluded from the statistical analysis.

Both corn silages had been harvested in the fall of 2005 and had been ensiled in walled bunker silos for approximately $11 \mathrm{mo}$ at the start of the trial. The experimental period extended from approximately $3 \mathrm{wk}$ prepartum to $3.5 \mathrm{wk}$ postpartum, with weekly assignments when animals were within $24 \mathrm{~d}$ of their projected calving date, and weekly removal from experimental diets when they were beyond 21 DIM. All cows were fed a common diet (lactation diet) after this, and data were collected through 105 DIM. Prepartum animals were exercised at least 3 times per week in a gravel paddock. Cows were housed in tie-stalls $(183 \mathrm{~cm}$ long $\times 137 \mathrm{~cm}$ wide) with rubber mats and bedded with sawdust.

Cows were fed either CCS (multiple varieties selected for corn silage and layered within a bunker silo; see Table 1 for analyses) or BMRCS during the approximately 3.5-wk precalving (CU-CCS, CU-BMR) and postcalving (Fr-CCS, Fr-BMR) periods. After this, they were all fed a common diet (lactation diet) containing only CCS. Diets were formulated with CPM Dairy version 3.0 software (Cornell University, University of Pennsylvania, and the Miner Institute) using the following animal descriptions: prepartum diets - second lactation, 35 mo old, $270 \mathrm{~d}$ pregnant, $640-\mathrm{kg}$ cow consuming $12.5 \mathrm{~kg}$ of DMI; postpartum diets - second lactation, 35 mo old, 12 DIM, 640-kg cow producing 38.5 $\mathrm{kg}$ of milk with $3.70 \%$ milk fat and $3.10 \%$ true protein and consuming $20.3 \mathrm{~kg}$ of DMI; lactation diet - second lactation, 37 mo old, 50 DIM, 640-kg cow producing $40.8 \mathrm{~kg}$ of milk with $3.60 \%$ milk fat and $3.00 \%$ true protein and consuming $22.8 \mathrm{~kg}$ of DMI. The objective in formulating the pre- and postpartum diets was that the 2 diets containing either CCS or BMRCS would differ only in the NDF digestibility of the corn silage (Table 2). High-moisture shelled corn was not included in the transition diets, and some fermentable fiber sources (soybean hulls, citrus pulp, wheat middlings, or their combination) were substituted for corn meal to reduce the possibility of propionate altering meal patterns and reducing DMI (Allen et al., 2009). Wheat straw was included at approximately $18 \%$ of ration DM in the prepartum diets to decrease dietary energy levels closer to the animal's requirement. Physically effective NDF levels were formulated using CPM Dairy version 3.0 tabular values to be approximately $22.5 \%$ of ration DM in the postpartum diets. Both pre- and postpartum diets were designed to have the same ratio of lysine to methionine (3:1) as predicted by CPM Dairy. Biochlor (Arm and Hammer Animal Nutrition, Princeton, NJ) was added to the prepartum diets to decrease the DCAD level. The inclusion level of Biochlor differed between prepartum diets (Table 2) in an attempt to provide the same DCAD level to both treatments. Similarly, potassium carbonate (DCAD Plus; Arm and Hammer Animal Nutrition) was added to the postpartum diets to increase the DCAD level of both diets and equilibrate it across diets. 
Table 1. Chemical composition of conventional corn silage (CCS) and brown midrib corn silage (BMRCS) ${ }^{1}$

\begin{tabular}{|c|c|c|c|c|}
\hline Item & CCS & SEM & BMRCS & SEM \\
\hline $\mathrm{DM}, \%$ & 31.2 & 0.9 & 29.8 & 0.7 \\
\hline $\mathrm{CP}, \%$ & 8.5 & 0.4 & 9.1 & 0.3 \\
\hline Soluble protein, $\%$ of CP & 65.7 & 1.0 & 60.1 & 1.9 \\
\hline ADICP, $\%$ & 0.9 & 0.02 & 0.8 & 0.03 \\
\hline NDICP, \% & 1.0 & 0.05 & 1.1 & 0.04 \\
\hline $\mathrm{NH}_{3}, \%$ of $\mathrm{CP}$ & 12.5 & 0.8 & 10.0 & 0.4 \\
\hline $\mathrm{ADF}, \%$ & 26.1 & 0.2 & 25.8 & 0.6 \\
\hline NDF, $\%$ & 44.1 & 0.5 & 45.5 & 0.7 \\
\hline Lignin, \% & 3.2 & 0.1 & 2.3 & 0.2 \\
\hline NDF digestibility, $30 \mathrm{~h}$ in vitro, $\%$ & 56.8 & 2.1 & 73.8 & 0.9 \\
\hline NDF $k_{d}{ }^{2}, \% / h$ & 3.8 & 0.1 & 5.4 & 0.1 \\
\hline Starch, \% & 26.2 & 0.3 & 23.5 & 0.2 \\
\hline In vitro 7-h starch digestibility, \% & 82.0 & 0.2 & 76.1 & 0.2 \\
\hline Sugar, \% & 1.1 & 0.3 & 2.4 & 0.2 \\
\hline NFC, $\%$ & 41.1 & 0.8 & 39.0 & 0.7 \\
\hline Fat, \% & 3.6 & 0.1 & 3.4 & 0.1 \\
\hline Ash, \% & 3.7 & 0.3 & 3.9 & 0.30 \\
\hline Total VFA, \% & 9.6 & 0.7 & 10.4 & 0.2 \\
\hline Lactate & 7.7 & 0.7 & 7.8 & 0.3 \\
\hline Acetate & 1.9 & 0.1 & 2.6 & 0.2 \\
\hline $\mathrm{pH}$ & 3.72 & 0.02 & 3.74 & 0.03 \\
\hline Calcium & 0.25 & 0.02 & 0.33 & 0.02 \\
\hline Phosphorus & 0.22 & 0.008 & 0.25 & 0.02 \\
\hline Magnesium & 0.19 & 0.01 & 0.29 & 0.02 \\
\hline Potassium & 1.21 & 0.16 & 1.12 & 0.08 \\
\hline Sodium & 0.01 & 0.00 & 0.02 & 0.01 \\
\hline Sulfur & 0.12 & 0.01 & 0.12 & 0.01 \\
\hline Chloride & 0.16 & 0.02 & 0.16 & 0.02 \\
\hline \multicolumn{5}{|l|}{ Particle size $^{3}$} \\
\hline$>19 \mathrm{~mm}, \%$ as-fed & 24 & & 26 & \\
\hline 8 to $19 \mathrm{~mm}, \%$ as-fed & 59 & & 59 & \\
\hline$<8 \mathrm{~mm}, \%$ as-fed & 17 & & 15 & \\
\hline
\end{tabular}

${ }^{1}$ Corn silage results are the averages from 7 composites consisting of 4 consecutive weeks of samples per composite. Values are percentage of DM unless noted. ADICP $=$ acid detergent insoluble CP; NDICP $=$ neutral detergent insoluble $\mathrm{CP}$.

${ }^{2} \mathrm{NDF} \mathrm{k}_{\mathrm{d}}$ calculated as per Van Amburgh et al. (2003).

${ }^{3}$ Determined using the Penn State Particle Separator (Lammers et al., 1996; Kononoff et al., 2003).

\section{Data Collection, Sampling Procedures, and Analytical Methods}

The TMR was fed once daily using individual fiberglass tubs in an amount to ensure at least $5 \%$ orts. Rations were prepared in mixer wagons (Richard Keenan \& Co. Ltd., Carlow, Ireland) and delivered to the cows with Data Rangers (American Calan, Northwood, $\mathrm{NH})$. Orts were vacuumed and weighed via the Data Rangers. The electronic feed monitoring program Feed Watch (Valley Agricultural Software, Tulare, CA) was used in TMR preparation and to monitor the exact amounts of ingredients used during the daily preparation of rations. Forage DM was determined weekly and feeding rates were adjusted accordingly.

Cows were milked 3 times daily in a milking parlor. Milk was sampled from all 3 milkings on a weekly basis, composited into a single sample, and stored at $4^{\circ} \mathrm{C}$ with a milk preservative (Bronopol tablet; D \& F Control System, San Ramon, CA) for midinfrared analysis of fat, protein, and lactose contents (AOAC International, 2000; method 972.160) and SCC by optical fluorescent analysis (AOAC International, 2000; method 978.26; Dairy One Cooperative Inc., Ithaca, NY). Cows were weighed and scored for body condition (Wildman et al., 1982) 5 times throughout the study (wk $-3,1,3,9$, and 15 relative to calving). Blood samples were collected immediately before feeding into $10-\mathrm{mL}$ vials containing citrate from the coccygeal artery or vein on a weekly basis from wk -3 to 3 . Samples were centrifuged $(2,800$ $\times g, 15 \mathrm{~min}$ at $4^{\circ} \mathrm{C}$ ), and the plasma was collected and then frozen at $-20^{\circ} \mathrm{C}$ until subsequent analysis. Plasma concentrations of NEFA and BHBA were determined by enzymatic analysis (NEFA-C, WAKO Pure Chemical Industries, Osaka, Japan; BHBA dehydrogenase, kit no. 310, Sigma Chemical). All spectrophotometric measurements were conducted using a Versamax tunable microplate reader (Molecular Devices, Sunnyvale, CA).

Samples of feedstuffs, ingredient mixes, and TMR were collected on a weekly basis. A subsample was 
Table 2. Ingredient composition of diets fed to Holstein cows during the prepartum, postpartum, and lactation periods ${ }^{1}$

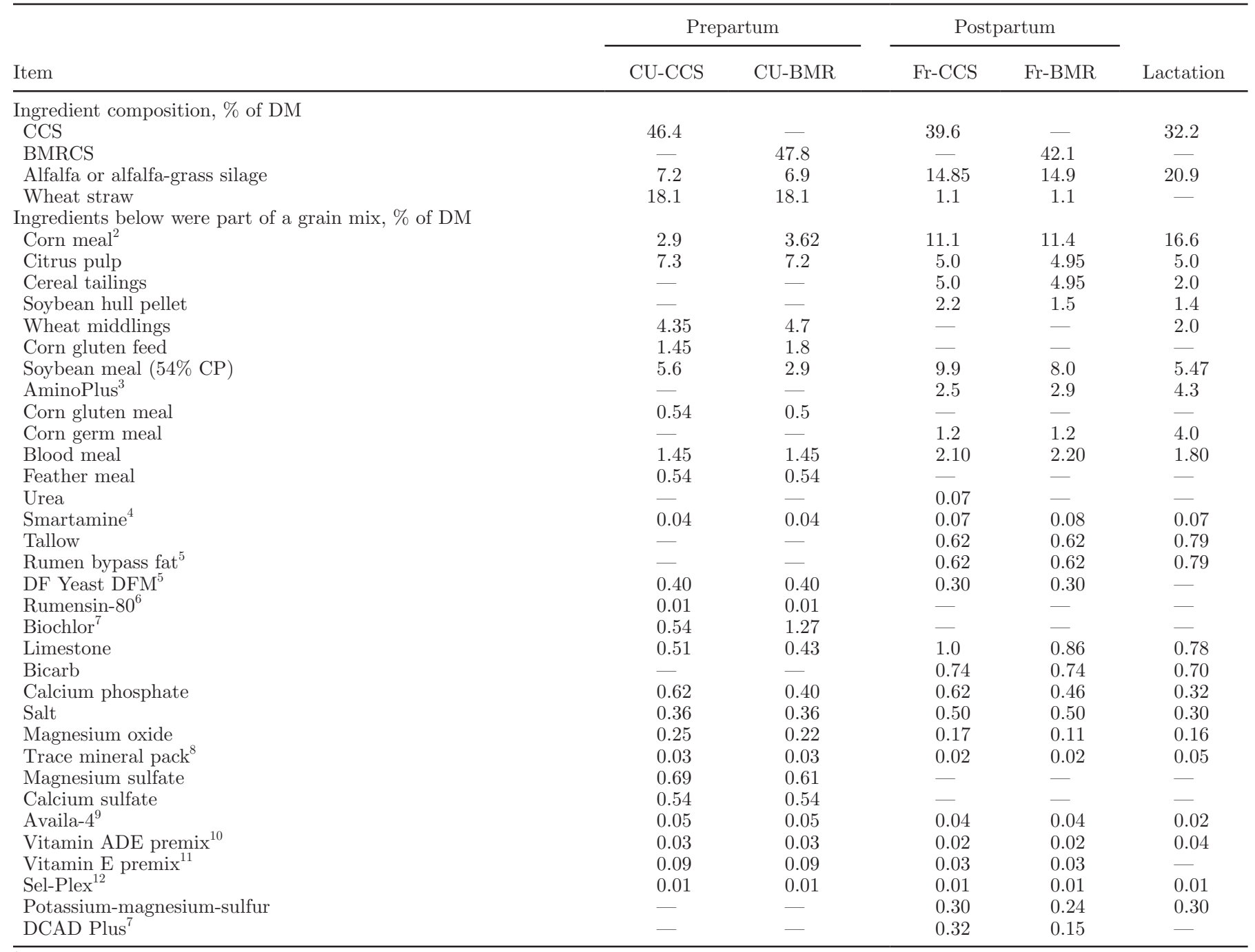

${ }^{1}$ Cows were fed either conventional corn silage (CCS) or brown midrib corn silage (BMRCS) during both the prepartum (CU-CCS, CU-BMR) and postpartum (Fr-CCS, Fr-BMR) periods, after which they were fed a common diet (lactation diet) containing CCS.

${ }^{2}$ Corn meal was not included in the grain mix for cows fed the lactation diet.

${ }^{3}$ Ag Processing Inc. (Omaha, NE).

${ }^{4}$ Adisseo (Atlanta, GA).

${ }^{5}$ Cargill Animal Nutrition (Minneapolis, MN).

${ }^{6}$ Elanco (Greenfield, IN). Fed at a rate to provide $320 \mathrm{mg}$ of Rumensin- 80.

${ }^{7}$ Arm and Hammer Animal Health (Princeton, NJ).

${ }^{8}$ Contained 112,245 mg of zinc/kg, 19,387 mg of copper $/ \mathrm{kg}, 91,836 \mathrm{mg}$ of manganese $/ \mathrm{kg}, 2,551 \mathrm{mg}$ of cobalt $/ \mathrm{kg}$, and 1,938 mg of iodine/kg.

${ }^{9}$ Zinpro Corporation (Eden Prairie, MN).

${ }^{10}$ Contained $97,130 \mathrm{kIU}$ of vitamin $\mathrm{A} / \mathrm{kg}, 7,218 \mathrm{kIU}$ of vitamin $\mathrm{D} / \mathrm{kg}$, and $72 \mathrm{kIU}$ of vitamin $\mathrm{E} / \mathrm{kg}$.

${ }^{11}$ Contained $110 \mathrm{kIU}$ of vitamin $\mathrm{E} / \mathrm{kg}$.

${ }^{12}$ Alltech (Nicholasville, KY).

dried at $60^{\circ} \mathrm{C}$ in a forced-air oven for $48 \mathrm{~h}$ to determine DM content. A second subsample was frozen at $-20^{\circ} \mathrm{C}$. Forage DM was adjusted on a weekly basis using the determined DM values. The dried samples were ground through a 2-mm screen in a Wiley mill and composited at 4 -wk intervals. Weekly corn silage samples that had been frozen were thawed and combined into a 4-wk composite. The dried and silage samples were submitted for wet chemistry analysis (Cumberland Valley Analytical Services, Hagerstown, MD; Table 3). Nitrogen was determined using a Leco FP-528 nitrogen combustion analyzer (Leco, St. Joseph, MI) using method 
990.03 (AOAC International, 2000). Crude protein was reported as nitrogen multiplied by 6.25 . Acid detergent fiber (method 973.18) and ash (method 942.05) were determined (AOAC International, 2000). Neutral detergent fiber was determined by the method of Van Soest et al. (1991). Fat was determined using method 2003.05 (AOAC International, 2006). Lignin and neutral detergent fiber digestibility were determined according to the method of Goering and Van Soest (1970). Minerals were determined using PerkinElmer $3300 \mathrm{XL}$ and $5300 \mathrm{~V}$ inductively coupled plasma mass spectrometers (PerkinElmer, Shelton, CT). Soluble protein was analyzed using a borate-phosphate procedure (Krishnamoorthy et al., 1982). Starch was determined using a correction for free glucose (Hall, 2009). A colorimetric method was used for sugar analysis (DuBois et al., 1956). The wet forage composites were analyzed to determine silage VFA using a PerkinElmer gas chromatograph with a Restek column packed with Stabilwax-DA (PerkinElmer). Lactic acid was determined on a silage extract $(25 \mathrm{~g}$ of wet silage plus $200 \mathrm{~mL}$ of deionized water) using an YSI 2700 Elect Biochemistry Analyzer (YSI Inc., Yellow Springs, OH).

\section{Calculations and Estimates}

The feeding software program (Feed Watch) recorded the exact amounts of each ingredient that were used to prepare a daily ration. The daily feeding results were compiled over 4 -wk periods to determine the average amount of each ingredient used in the preparation of diets during the pre- and postcalving experimental periods. These results, along with the corresponding corn silage and haylage 4 -wk composite results, were entered into CPM Dairy version 3.0 to calculate a dietary $\mathrm{NE}_{\mathrm{L}}$ for that 4 -wk period. Net energy intake was determined individually for each cow by multiplying $\mathrm{DMI}$ by the calculated mean dietary $\mathrm{NE}_{\mathrm{L}}$ for that time period. The requirements of $\mathrm{NE}_{\mathrm{M}}$, net energy for pregnancy, and $\mathrm{NE}_{\mathrm{L}}$ were calculated according to the NRC (2001) requirements. Energy balance was expressed as a percentage of the requirement. Dietary NDF, forage NDF, lignin, available and unavailable NDF, starch, soluble fiber, ether extract, $\mathrm{NE}_{\mathrm{L}}$, and silage acids were calculated in the same manner for each 4 -wk period; these 4-wk period results were then averaged across all periods to obtain a calculated study average for each of these dietary components.

Energy-corrected milk was calculated from the energy output in milk using the equation by Tyrrell and Reid (1965), namely, $\mathrm{NE}_{\mathrm{L}}(\mathrm{Mcal} / \mathrm{d})=$ milk yield $(\mathrm{kg} / \mathrm{d})$ $\times[(0.0909 \times \%$ fat $)+(0.0563 \times \%$ true protein $)+$ $(0.0395 \times \%$ lactose $)]$, divided by the assumed energy content of $4 \% \mathrm{FCM}$ of $0.749 \mathrm{NE}_{\mathrm{L}}(\mathrm{Mcal} / \mathrm{kg}$ ).

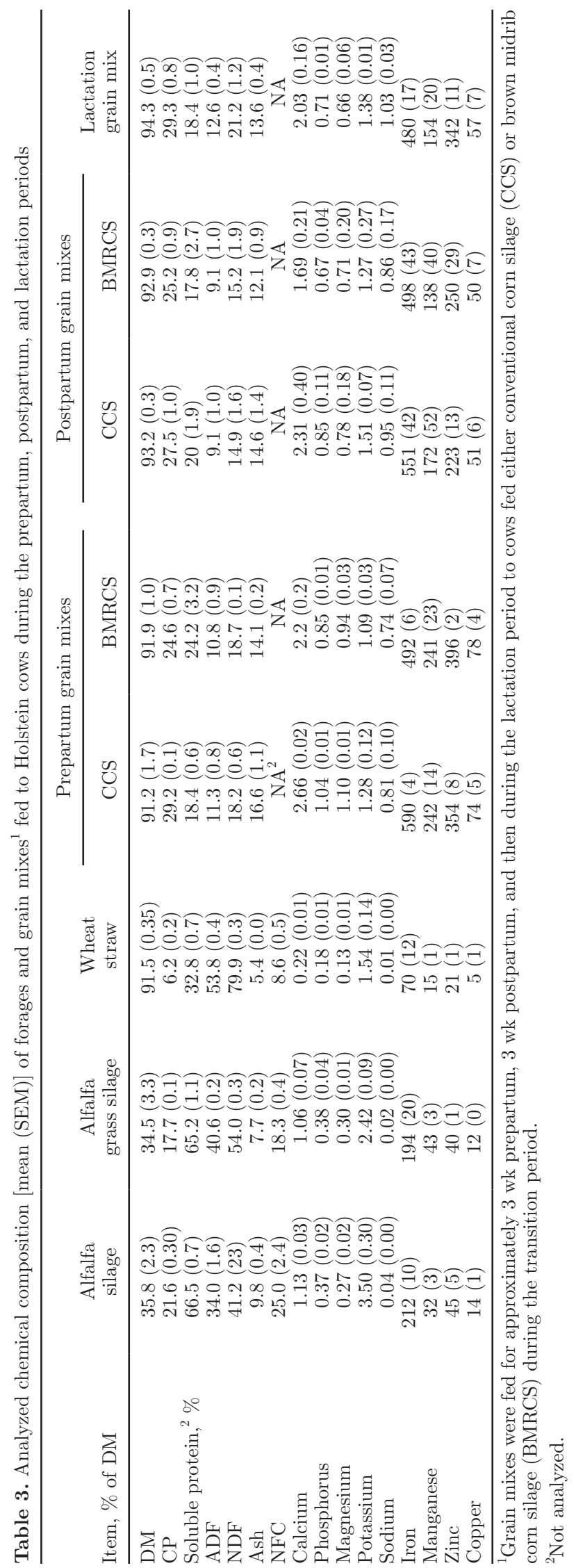

Journal of Dairy Science Vol. 95 No. 11, 2012 


\section{Statistical Analyses}

Cows were blocked by parity for treatment assignment, but data across parities were combined for statistical analysis. Data were subjected to ANOVA for a completely randomized design with repeated measures using the MIXED procedure of SAS (2001; SAS Institute Inc., Cary, NC). The model included the fixed effects of treatment, time, and the interaction of treatment and time. The random effect was cow nested within treatment. Each cow's previous lactation mature-equivalent 305-d milk yield was used as a covariate during analysis of milk yield and milk composition and retained in the model if $P<0.20$. Similarly, each cow's linear score (LS) at dry-off was used as a covariate during analysis of milk yield, LS, and SCC and retained in the model if $P<0.20$. Data from cows with mastitis during the first $6 \mathrm{wk}$ of lactation were included in the statistical analysis, whereas data generated during a mastitis episode from wk 7 to 15 were excluded from the statistical analysis. For each variable, cow was subjected to 4 covariance structures (first-order autoregressive, heterogeneous first-order autoregressive, compound symmetry, heterogeneous compound symmetry). The structure yielding the smallest Akaike's information criterion was selected. The Kenward-Rogers method was used for calculation of denominator degrees of freedom. Fisher's exact test (2-sided) was used to analyze categorical health data.

\section{RESULTS}

\section{Corn Silages and Rations}

The CCS and BMRCS were very similar in chemical composition (Table 1$)$. The CCS (31.2\% of DM) was more mature than the BMRCS (29.8\% of DM), which may have, at least in part, contributed to its lower NDF (44.1 vs. $45.5 \%$ ) and considerably higher starch (26.2 vs. $23.5 \%$ ) levels. Despite both corn silages being ensiled for more than a year for most of the study, the 7-h starch digestibility was higher in the CCS than the BMRCS (82.0 vs. $76.1 \%$ ). As expected, lignin levels were lower, and 30-h NDF digestibility was higher, in the BMRCS than in the CCS (2.3 and 3.1\% for lignin, and 73.8 and $56.8 \%$ for NDF digestibility). Lactate, VFA, and particle size were very similar between corn silages. In pretrial analyses of the corn silages, the NDF had been higher and potassium content lower in the CCS than in the BMRCS.

The composition of both prepartum diets was similar in most aspects (Table 4). As expected, lignin levels were lower in the CU-BMR diet (3.6 vs. 4.0\%). This, along with the higher estimated fractional rate of potentially digestible NDF $\left(\mathrm{NDF}_{\mathrm{d}}\right)$ for BMRCS (Table 1 ), resulted in a higher calculated $\mathrm{NE}_{\mathrm{L}}$ level in the CU-BMR diet than in the CU-CCS diet (1.53 vs. 1.48 Mcal/kg of DM, respectively). Calcium was higher in the CU-CCS diet than in the CU-BMR diet, whereas the DCAD did not differ (0.95 vs. $0.77 \%$, and 2.9 vs. $2.3 \mathrm{mEq} / 100 \mathrm{~g})$.

The diets fed during the postpartum period were also similar in chemical composition. As expected, lignin was lower in the Fr-BMR treatment than in the Fr-CCS treatment (2.4 vs. $2.8 \%$; Table 4 ). Crude protein was numerically lower in the Fr-CCS treatment.

\section{Intake and Production}

Both groups of cows were fed the treatment diets for an average of $22 \mathrm{~d}(\mathrm{SD}=6 \mathrm{~d})$ before calving. Intakes between the 2 treatments were similar from wk -3 to -2 precalving (Figure 1), and then declined more the final 2 wk preceding calving in cows fed the CU-CCS as compared with the CU-BMR treatment. Cows fed BMRCS ate more feed during the 2 -wk period preceding calving (14.3 vs. $13.2 \mathrm{~kg} / \mathrm{d}$ of DMI; $P<0.03$; Table 5 ) and during the 3 -wk postcalving period (20.1 vs. 18.1 $\mathrm{kg} / \mathrm{d}$ of DMI; $P<0.01$; Table 5 ) than did cows fed the CCS diets. Intake of indigestible NDF, as calculated by CPM Dairy version 3.0, was similar in both groups during the pre- and postpartum periods. As expected, the calculated intake of digestible NDF was numerically greater in the BMR treatment than in the CCS treatment (Table 6).

Cows fed BMR during the transition period produced more milk, lactose, and TS during the 3-wk postpartum period and tended to produce more FCM (Figure 2) and fat than did cows fed CCS during this period (Table 5). Milk urea nitrogen levels were lower $(P=0.04)$ in the postpartum period for cows fed the BMRCS.

Significant carryover effects were observed from the transition period to the wk 4 to 15 period when all cows were fed a common diet. Cows that had been fed BMRCS during the transition period produced more true protein $(1.36$ vs. $1.30 \mathrm{~kg} / \mathrm{d}, P=0.04)$, lactose $(2.24$ vs. $2.12 \mathrm{~kg} / \mathrm{d}, P=0.04)$, and TS (5.82 vs. 5.51 $\mathrm{kg} / \mathrm{d}, P=0.03)$, and tended to produce more FCM $(49.4$ vs. $46.7 \mathrm{~kg} / \mathrm{d}, P=0.09), \mathrm{ECM}(44.2$ vs. $41.6, P$ $=0.07)$, and fat $(1.78$ vs. $1.67 \mathrm{~kg} / \mathrm{d}, P=0.08)$ than did cows that had been fed CCS during the transition period (Table 5). Production of FCM, ECM, and fat all tended to be higher in cows fed BMRCS during the transition period. Production efficiencies and DMI did not differ between the 2 treatments during this time period. 
Table 4. Analyzed and calculated ${ }^{1}$ chemical composition [mean (SEM)] of diets fed to Holstein cows during the prepartum, postpartum, and lactation periods ${ }^{2}$

\begin{tabular}{|c|c|c|c|c|c|}
\hline Item & \multicolumn{2}{|c|}{ Prepartum } & \multicolumn{2}{|c|}{ Postpartum } & Lactation \\
\hline DM \% & $43.1(1.4)$ & $42.3(1.1)$ & $43.1(1.3)$ & $41.9(1.0)$ & $43.6(0.9)$ \\
\hline \multicolumn{6}{|c|}{ Chemical composition, \% of DM } \\
\hline $\mathrm{CP}$ & $13.8(0.3)$ & $13.5(0.4)$ & $17.6(0.4)$ & $16.8(0.4)$ & $17.0(0.4)$ \\
\hline Soluble protein, $\%$ of CP & $42.0(0.4)$ & $45.6(0.4)$ & $42.4(1.0)$ & $41.3(1.9)$ & $40.1(1.4)$ \\
\hline Forage $\mathrm{NDF}^{1}$ & $38.5(0.50)$ & $38.9(0.4)$ & $26.2(0.3)$ & $27.3(0.4)$ & $24.4(0.3)$ \\
\hline $\operatorname{Lignin}^{1}$ & $4.0(0.1)$ & $3.6(0.1)$ & $2.8(0.1)$ & $2.4(0.0)$ & $2.9(0.1)$ \\
\hline Starch $^{1}$ & $17.4(0.6)$ & $16.2(0.3)$ & $22.7(0.6)$ & $21.2(0.8)$ & $23.4(0.4)$ \\
\hline $\mathrm{NFC}^{1}$ & $31.7(0.9)$ & $31.5(0.8)$ & $39.8(0.6)$ & $39.4(0.6)$ & $38.7(0.6)$ \\
\hline Soluble fiber ${ }^{3}$ & $6.5(0.5)$ & $7.3(0.3)$ & $5.9(0.0)$ & $7.2(0.8)$ & $7.3(0.6)$ \\
\hline Silage acids ${ }^{1}$ & $5.0(0.4)$ & $5.7(0.2)$ & $5.8(0.3)$ & $5.9(0.2)$ & $5.4(0.2)$ \\
\hline Ether extract $^{1}$ & $3.0(0.0)$ & $3.0(0.0)$ & $4.4(0.0)$ & $4.4(0.0)$ & $4.4(0.4)$ \\
\hline Potassium & $1.18(0.04)$ & $1.18(0.06)$ & $1.44(0.02)$ & $1.28(0.04)$ & $1.45(0.06)$ \\
\hline Sodium & $0.20(0.00)$ & $0.22(0.01)$ & $0.41(0.01)$ & $0.41(0.03)$ & $0.35(0.01)$ \\
\hline Sulfur ${ }^{1}$ & $0.38(0.00)$ & $0.37(0.00)$ & $0.26(0.01)$ & $0.25(0.0)$ & $0.28(0.01)$ \\
\hline Chloride $^{1}$ & $0.43(0.01)$ & $0.50(0.01)$ & $0.48(0.01)$ & $0.47(0.0)$ & $0.40(0.01)$ \\
\hline $\mathrm{DCAD},{ }^{4} \mathrm{mEq} / 100 \mathrm{~g}$ & $2.9(1.0)$ & $2.3(1.9)$ & $24.5(1.1)$ & $21.0(2.0)$ & $25.2(0.8)$ \\
\hline Iron, $\mathrm{mg} / \mathrm{kg}$ & $401(50)$ & $286(35)$ & $361(9)$ & $273(12)$ & $277(17)$ \\
\hline Manganese, $\mathrm{mg} / \mathrm{kg}$ & $81(6)$ & $76(2)$ & $78(5)$ & $72.6(5)$ & $80(5)$ \\
\hline Zinc, $\mathrm{mg} / \mathrm{kg}$ & $113(10)$ & $108(1)$ & $114(4)$ & $111(6)$ & $114(6)$ \\
\hline Copper, $\mathrm{mg} / \mathrm{kg}$ & $24(2)$ & $27(4)$ & $26(3)$ & $23(2)$ & $24(3)$ \\
\hline
\end{tabular}

${ }^{1}$ All analyses were performed with wet chemistry procedures (Cumberland Valley Analytical Services, MD). These results were calculated on a 4-wk-period basis and averaged across all periods for a trial average. Forages were sampled on a weekly basis and made into composites consisting of 4 consecutive weeks, which were subsequently submitted for analysis. Feed Watch (Valley Agricultural Software, Tulare, CA) data were recorded on a daily basis. The daily measurements were averaged across the same 4 -wk period as for the forage composite to determine the amount of each ingredient used during daily load preparations. The forage composites and Feed Watch results were then used to calculate dietary components with CPM Dairy version 3.0 for each 4 -wk period.

${ }^{2}$ Cows were fed either conventional corn silage (CCS) or brown midrib corn silage (BMRCS) during both the prepartum (CU-CCS, CU-BMR) and postpartum (Fr-CCS, Fr-BMR) periods, after which they were fed a common diet (lactation diet) containing CCS.

${ }^{3}$ Soluble fiber was calculated by difference $([\mathrm{NFC}-($ starch + silage acids + water-soluble carbohydrate + NDICP $])$ using the average analytical values of forages used in the study. NDICP $=$ neutral detergent insoluble $\mathrm{CP}$.

${ }^{4} \operatorname{DCAD}(\mathrm{mEq} / 100 \mathrm{~g})=[(\%$ sodium $/ 0.023)+(\%$ potassium $/ 0.039)]-[(\%$ sulfur $/ 0.016)+(\%$ chlorine $/ 0.0355)]$.

\section{NEFA, BHBA, and Energy Balance}

Cows consuming the CU-BMR diet consumed significantly more energy during the prepartum period than did those fed the CU-CCS diet, but both groups consumed in excess of $150 \%$ of the NRC (2001) estimated requirements during this period (Table 7 ). A trend was observed for less of a decline in calculated energy balance $(\mathrm{Mcal} / \mathrm{d})$ as parturition approached in the CUBMR treatment than in the CU-CCS treatment $(P=$ 0.07; Table 7). Calculated energy balance during the 3 -wk postpartum period did not differ between treatments. Prepartum NEFA and postpartum NEFA and BHBA levels did not differ between treatments. Body weights and BCS (Table 5) and their interaction by week (data not shown) did not differ between treatments.

\section{Postpartum Health}

A trend ( $P=0.09,2$-sided Fisher's exact test) was observed for a reduction in health disorders (Table 8), as well as a trend for a reduction in SCC (166 vs. 559, $P=0.08)$ and LS (2.81 vs. $3.42, P=0.10$; Table 5$)$ in cows fed the BMRCS during the transition period.

\section{DISCUSSION}

\section{Diets and Intake}

The primary differences between the prepartum diets resulted from the lower lignin and higher in vitro NDF digestibility (17 percentage points) in the BMRCS than the CCS. It is unlikely that the difference in calcium levels between the 2 diets influenced the incidence of 


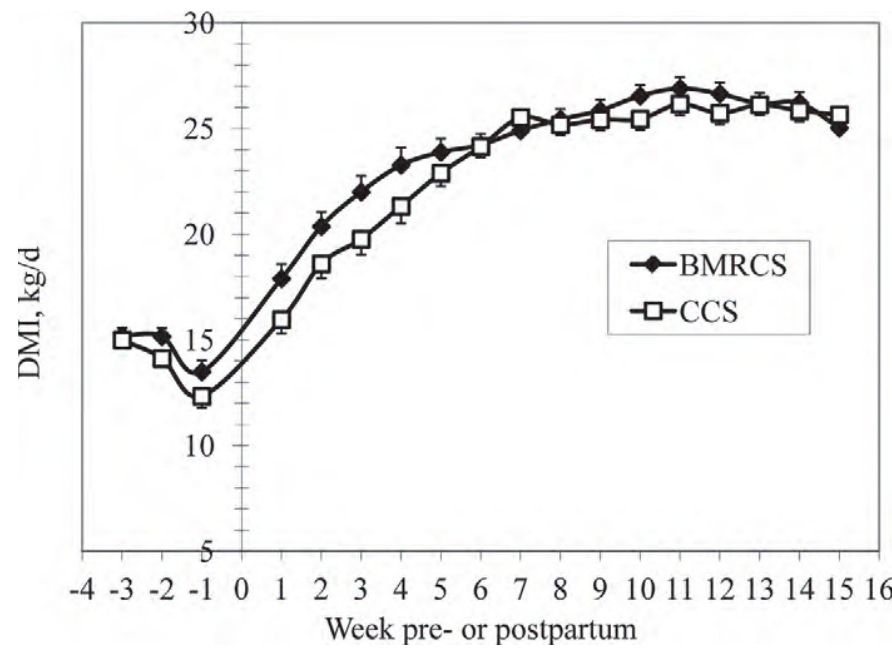

Figure 1. Dry matter intake in cows fed either conventional corn silage (CCS) or brown midrib corn silage (BMRCS) during both the prepartum and postpartum periods, followed by a common lactation diet containing CCS from wk 4 to 15.

hypocalcemia or related transition health disorders (Goff and Horst, 1997).

One of the primary regulators of intake is distension of the gastrointestinal tract. In ruminants, distension of the RR is usually thought to be the primary site where distension can limit intake (Allen, 1996). Fill of the RR is affected by both the NDF content of the diet and the rate of digestibility of the forage NDF (Oba and Allen, 1999b). Hayirli et al. (2002) evaluated factors affecting DMI during the prepartum period by using a data set from 16 experiments. Dry matter intake decreased linearly with increasing levels of NDF. Fill apparently limited intake in primiparous, but not multiparous, prepartum cows fed a diet consisting of $30 \%$ wheat straw and 48\% NDF (Janovick and Drackley, 2010). Additional rumen-inert bulk (water-filled bladders) reduced DMI in cows ranging from 28 to 70 DIM (Johnson and Combs, 1991). Thus, fill can limit intake in both prepartum cows and animals ranging from 28 to 70 DIM.

During the far-off dry period and before being assigned to this study, all dry cows were fed a diet consisting of $41 \%$ CCS, $28 \%$ alfalfa haylage, $8 \%$ wheat straw, and $23 \%$ grain, resulting in a ration that was approximately $42.5 \%$ NDF. The prepartum rations in this study contained $18 \%$ wheat straw and were approximately $45 \% \mathrm{NDF}$. It is possible that it took the first week for straw to slowly accumulate in the rumen and start to restrict intake in cows fed the CCS. Rumen fill may have occurred to a lesser extent in cows fed the BMRCS, with its greater ruminal NDF turnover rate (Oba and Allen, 2000), allowing intakes to remain higher before calving.

Table 5. The effect on production, intake, and production efficiencies of feeding cows either conventional corn silage (CCS) or brown midrib corn silage (BMRCS) during the transition period ${ }^{1}$

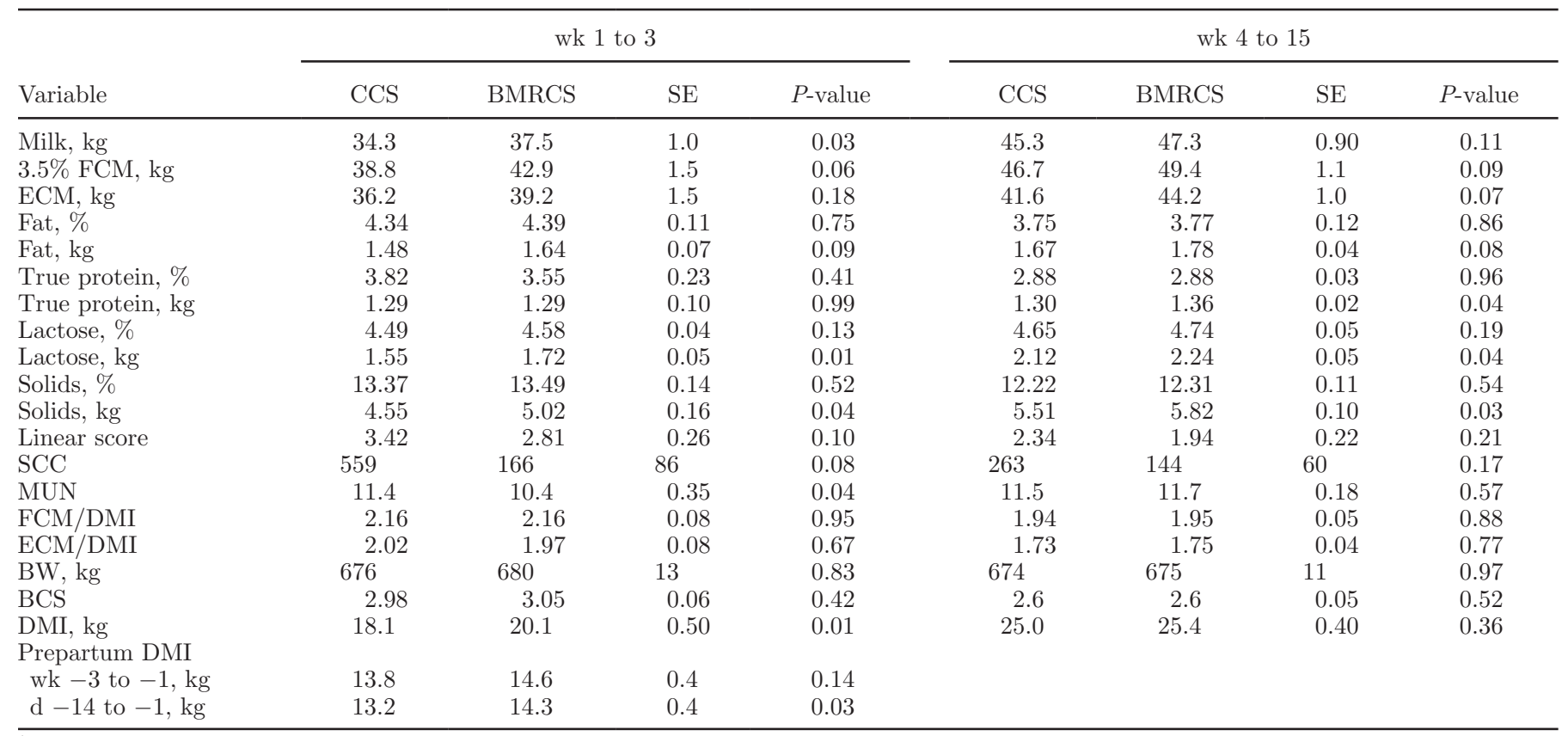

${ }^{1}$ Postpartum results are averages for the first $3 \mathrm{wk}$ of lactation when either corn silage was fed, and for the subsequent 12 wk of lactation when only CCS was fed. Cows were fed either CCS or BMRCS corn silage during both the prepartum (CU-CCS, CU-BMR) and postpartum (Fr-CCS, Fr-BMR) periods, after which they were fed a common diet (lactation diet) containing CCS. 


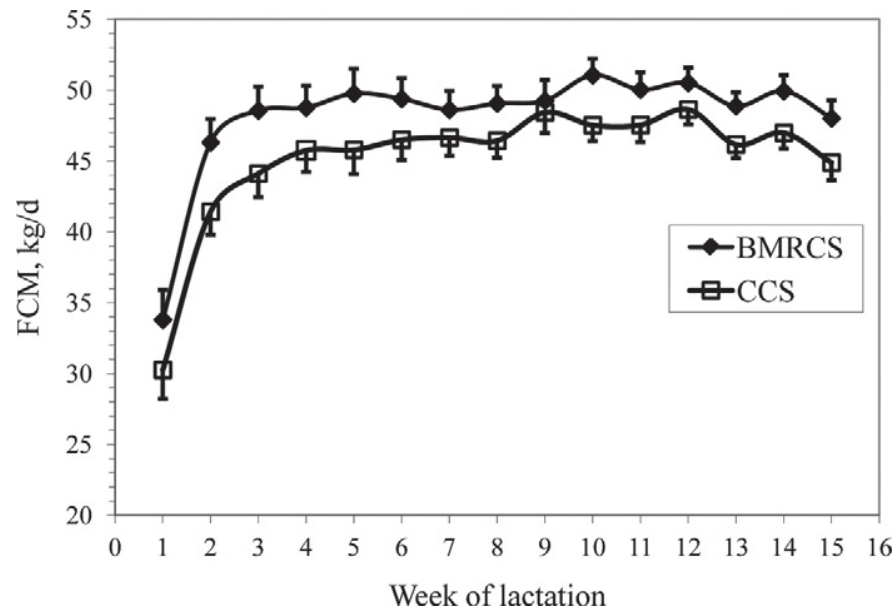

Figure 2. The 3.5\% FCM production in cows fed either conventional corn silage (CCS) or brown midrib corn silage (BMRCS) during both the prepartum and postpartum periods, followed by a common lactation diet containing CCS from wk 4 to 15 .

Diets with higher NDF digestibility did not improve intakes in the prepartum period when beet pulp was used to replace a portion of oat hay (Dann et al., 2007). However, both the control and beet pulp diets were lower in NDF than were the prepartum diets in this study [approximately $41 \%$ in the study by Dann et al. (2007) vs. $45 \%$ in this study]. Additionally, oat hay is generally more digestible than wheat straw (CPM Dairy version 3.0). Thus, fill was less likely to be limiting intake in the control cows, which is likely the reason that no increase in intake occurred in the beet pulp treatment.

Because the NDF levels between treatments in both the pre- and postpartum diets were similar, the increase in DMI observed in the BMRCS treatments was likely due to its NDF breaking down and exiting the rumen more quickly, allowing for the consumption of more TMR. Thus, the increased DMI observed in cows consuming the CU-BMR diet was probably due to a reduction in RR fill occurring from the BMRCS breaking down more quickly, allowing for increased intake.

In this study, DMI was significantly greater in the last 2 wk of gestation, and a trend was observed for less of a decline in calculated energy balance in the CU-BMR than in the CU-CCS treatment as parturition approached (Tables 5 and 7). Grummer et al. (2004) pooled data from 3 transition studies to evaluate the effects of either the magnitude of decline in DMI from $3 \mathrm{wk}$ precalving to $1 \mathrm{~d}$ precalving or DMI during the third week precalving on liver triglycerides (TG) $1 \mathrm{~d}$ postcalving. The investigators found a significant reduction in liver TG accumulation as the magnitude of the decrease in DMI during the final 3 wk of gestation lessened, whereas liver TG $1 \mathrm{~d}$ postcalving were not significantly affected by DMI at 3 wk prepartum. It is interesting that the level of DMI from $\mathrm{d}-21$ to -14 was positively and significantly $(P=0.0005)$ related to the level of DMI for the first $28 \mathrm{~d}$ of lactation, whereas the change in DMI before calving did not affect DMI after calving. Thus, it may be most beneficial for cows if they are able to have high DMI 14 to $21 \mathrm{~d}$ precalving and have little change in DMI as calving approaches. Essentially, this occurred in the feeding behavior transition study of Huzzey et al. (2007). In this study, cows identified as "healthy" according to postpartum vaginal discharges and temperatures had higher DMI 2 wk prepartum, declined less as calving approached, and then had higher intakes and production postpartum than did cows that were identified as being "severely metritic" postpartum. Considering all of this, at least some portion of the increased intakes observed in cows fed BMRCS during the postpartum period was likely due to the higher DMI in the prepartum period.

After calving, it is likely that the NDF in the BMRCS collapsed within and passed from the RR more quickly than what was occurring with the CCS NDF,

Table 6. Neutral detergent fiber and DMI during the prepartum and postpartum periods for cows fed either conventional corn silage (CCS) or brown midrib corn silage (BMRCS) during these time periods ${ }^{1}$

\begin{tabular}{lccccc}
\hline & \multicolumn{2}{c}{ Prepartum } & & \multicolumn{2}{c}{ Postpartum } \\
\cline { 2 - 3 } \cline { 5 - 6 } Item & CU-CCS & CU-BMR & & Fr-CCS & Fr-BMR \\
\hline DMI, 3 wk pre- or postpartum, kg & 13.2 & 14.3 & & 18.1 & 20.1 \\
Digestible NDF, ${ }^{2} \%$ of DM & 0.10 & 0.08 & & 0.07 & 0.06 \\
Indigestible NDF, ${ }^{2} \%$ of DM & 0.32 & 0.34 & & 0.24 & 0.25 \\
Digestible NDF, ${ }^{2 g}$ & 4.25 & 4.85 & & 4.41 & 5.10 \\
Indigestible NDF, ${ }^{2} \mathrm{~kg}$ & 1.27 & 1.22 & & 1.21 & 1.12 \\
\hline
\end{tabular}

${ }^{1}$ Cows were fed either CCS or BMRCS during both the 3-wk prepartum (CU-CCS, CU-BMR) and 3-wk postpartum (Fr-CCS, Fr-BMR) periods, after which they were fed a common diet (lactation diet) containing CCS for $12 \mathrm{wk}$.

${ }^{2}$ Calculations by CPM Dairy version 3.0 using study average DMI and forage analyses results. Indigestible NDF was calculated by multiplying the lignin amount by 2.4. Digestible NDF was altered by NDF digestion and passage rates. 
Table 7. Calculated energy balance and serum NEFA and BHBA concentrations from 3 wk prepartum to 3 wk postpartum for cows fed either conventional corn silage (CCS) or brown midrib corn silage (BMRCS) during this period

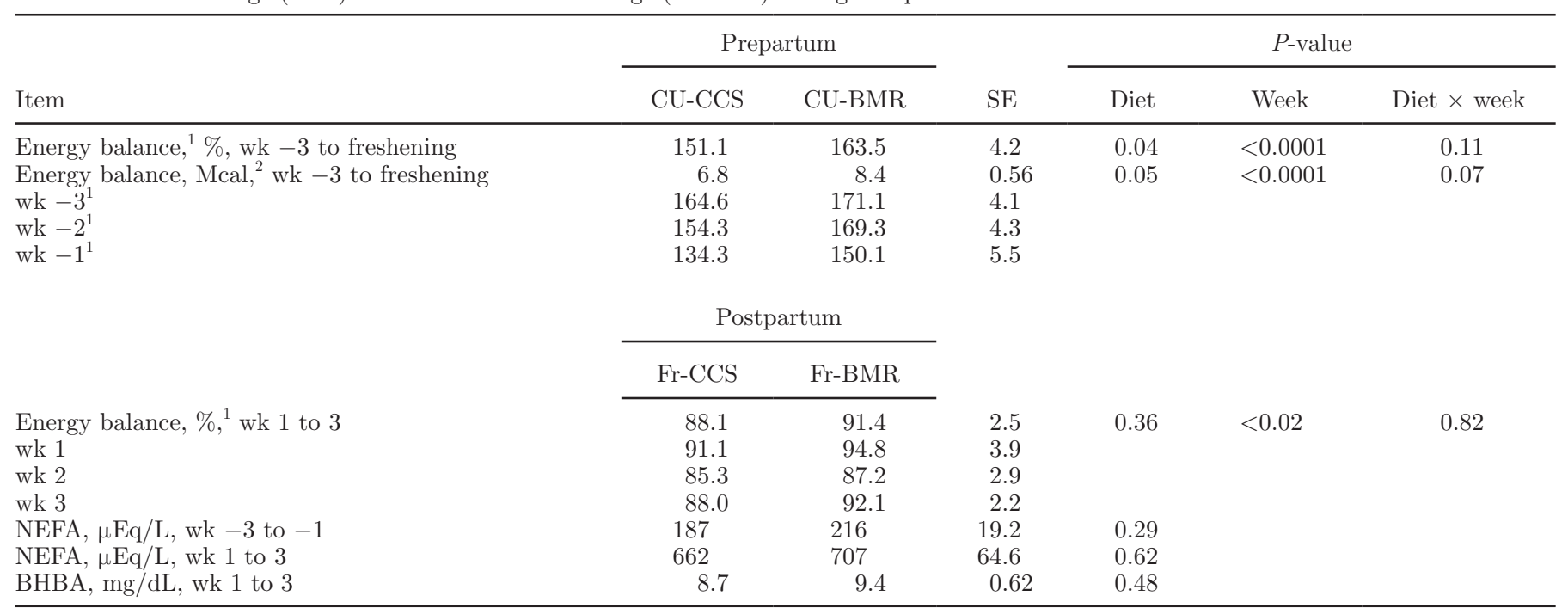

${ }^{1}$ Percentage of the $\mathrm{NE}_{\mathrm{L}}$ requirement (NRC, 2001). Cows were fed either conventional corn silage (CCS) or brown midrib corn silage (BMRCS) during both the prepartum (CU-CCS, CU-BMR) and postpartum (Fr-CCS, Fr-BMR) periods, after which they were fed a common diet (lactation diet) containing CCS.

${ }^{2} \mathrm{Mcal}$ in excess of the $\mathrm{NE}_{\mathrm{L}}$ requirement, NRC (2001).

which would also have contributed to higher intakes in the cows fed BMRCS. The indigestible NDF fraction is a factor that can influence fill and limit voluntary intake (Allen, 1996). In the present study, indigestible NDF was calculated by multiplying the lignin intake by 2.4 (CPM Dairy version 3.0). The calculated intakes of indigestible NDF in both treatments during both the 3 -wk pre- and 3-wk postpartum periods were similar. Possibly indigestible NDF influences intake more during the transition than at other stages of lactation.

Although it may seem to be a contradictory approach to include both very low (straw) and high (BMRCS) digestible NDF sources in high quantities in a prepartum ration, some biological reasons for this may exist. Straw provides a consistent ingredient that can help to keep consumed energy levels closer to requirements for dry cows. Additionally, it will persist in the rumen for some time postcalving, potentially helping to stabilize ruminal $\mathrm{pH}$ by providing buffering through cation exchange, and possibly by stimulating ruminal contractions and rumination. Highly digestible BMRCS, conversely, may help to maintain intake near the end of gestation, when rumen fill could be limiting. This increase in intake immediately precalving may enhance the immune status of the cow, improving productive performance postcalving (Huzzey et al., 2007). The lower MUN levels during the postpartum period in the Fr-BMR treatment were likely due to both the lower CP level in the Fr-BMR treatment and the increased digestibility of the BMRCS.

\section{Production}

The increased production in the Fr-BMR treatment during the first 3 wk of lactation was likely due to the

Table 8. Frequency of health disorders ${ }^{1}$ for Holstein cows fed either conventional corn silage (CCS) or brown midrib corn silage (BMRCS) during the transition period ${ }^{2}$

\begin{tabular}{lccc}
\hline Item & CU-CCS & CU-BMR & $P$-value \\
\hline${\text { Retained } \text { placenta }^{3}}_{\text {Metritis }^{4}}$ & 5 & 1 & NS \\
Ketosis $^{5}$ & 3 & 0 & NS \\
Ketosis with diarrhea $^{\text {Mastitis }}{ }^{6}$ & 1 & 0 & NS \\
wk 1-6 & 0 & 2 & NS \\
wk 7-15 & 3 & 2 & \\
Total health disorders, wk 1-6 & 7 & 4 & \\
\end{tabular}

${ }^{1}$ Two animals in the study were recorded as having had multiple disorders; however, only the first health disorder that an animal had during the $6 \mathrm{wk}$ after the freshening period was recorded in this table. One animal was listed as having had 2 cases of mastitis because the 2 events occurred more than 4 wk apart.

${ }^{2}$ Cows were fed either CCS or BMRCS during both the prepartum (CU-CCS, CU-BMR) and postpartum (Fr-CCS, Fr-BMR) periods, after which they were fed a common diet (lactation diet) containing CCS.

${ }^{3}$ The placenta was considered retained if it was still attached to the cow $24 \mathrm{~h}$ postcalving.

${ }^{4}$ Metritis was defined as a fetid, watery, brownish vaginal discharge.

${ }^{5}$ Ketosis was defined as urine testing moderate or greater with Ketostix (Bayer Corp., Elkhart, IN).

${ }^{6}$ Mastitis was defined as a hard, swollen quarter with visibly abnormal milk.

${ }^{7}$ Fisher's 2-sided exact test. 
higher intakes these animals experienced during this time. This may have been due to the BMRCS having a faster ruminal NDF digestion, degradation, and passage, allowing for the consumption of additional feed. It is most interesting that, as in the study by Santos et al. (2001), a carryover production response occurred from the transition period to wk 4 to 15 of lactation in the BMRCS treatments. This response (significantly greater protein and lactose yields, and a trend for increased FCM, ECM, and fat) may have occurred because these animals peaked higher during the transition period, and this increase in production was maintained after they were fed a common diet. A persistent increase in production could have occurred if cows fed BMRCS recruited more milk secretory cells, reduced the rate of secretory cell apoptosis, or increased the secretory activity of these cells. Possibly one or all of these events occurred if animals were in a more positive nutrient balance during the transition period. Dann et al. (1999) reported a similar carryover response when cows that were fed steam-flaked corn, as opposed to cracked corn, during the prepartum period and for the first $63 \mathrm{~d}$ of lactation continued to produce more milk after being switched to a common diet.

\section{NEFA, BHBA, and Energy Balance}

Although both treatment groups in this study declined less in calculated energy balance than what has been observed in other studies when cows consumed similar energy levels, they still declined more than cows fed closer to their requirements (Douglas et al., 2006; Janovick and Drackley, 2010). The lack of a significant difference in prepartum NEFA between treatments may have been partially because of the sampling frequency. Animals were bled only one time weekly during the transition period. The sampling interval may not have been frequent enough to detect treatment differences. An improvement in nutrient status can enhance immunity, leading to a decrease in immune-mediated transition disorders (Huzzey et al., 2007; Goff, 2006) and mastitis (Goff, 2006). Indications that animals fed the BMRCS were in a more positive nutrient status include the trends for the reduction in immune-mediated disorders, SCC, and LS during the transition period. This trend for an improvement in postpartum health may have contributed to the carryover production response observed from wk 4 to 15 in cows fed BMRCS during the transition period. An enhancement in immune function may occur if the energy balance declines less or is well in excess of NRC (2001) requirements during the final 2 to $3 \mathrm{wk}$ of gestation.

Postpartum NEFA and BHBA levels were very similar between treatments. This was expected, given the similarity in calculated energy balance levels during the postpartum period.

\section{CONCLUSIONS}

Cows fed BMRCS during the prepartum period consumed more feed during the last 2 wk of gestation, likely because of a reduction in fill. After parturition, either because of higher intakes during the prepartum period or because of a reduction in fill limitations in the postpartum period, cows fed BMRCS had higher intakes for the first $3 \mathrm{wk}$ postpartum. The increased intakes led to an increase in milk and solids yields during the 3 -wk postpartum period. A carryover effect occurred from the feeding of BMRCS during the transition period, resulting in significant increases in the yields of protein, lactose, and solids in these cows from wk 4 to 15 of lactation, when all cows were fed a common diet. The results of this study indicate the importance digestible NDF can have in transition diets, and the long-term production responses that can occur when intake is increased.

\section{ACKNOWLEDGMENTS}

We acknowledge Mycogen Seeds (Wooster, OH) for partial financial support of this research.

\section{REFERENCES}

Allen, M. S. 1996. Physical constraints on voluntary intake of forage by ruminants. J. Dairy Sci. 74:3063-3075.

Allen, M. S. 2000. Effects of diet on short-term regulation of feed intake by lactating dairy cattle. J. Dairy Sci. 83:1598-1624.

Allen, M. S., B. J. Bradford, and M. Oba. 2009. Board Invited Review: The hepatic oxidation theory of the control of feed intake and its application to ruminants. J. Anim. Sci. 87:3317-3334.

AOAC International. 2000. Official Methods of Analysis. 17th ed. AOAC Int., Gaithersburg, MD.

AOAC International. 2006. Official Methods of Analysis. 18th ed. AOAC Int., Gaithersburg, MD.

Cherney, J. H., D. J. R. Cherney, D. E. Akin, and J. D. Axtell. 1991. Potential of brown-midrib low-lignin mutants for improving forage quality. Adv. Agron. 46:157-198.

Dann, H. M., M. P. Carter, K. W. Cotanch, C. S. Ballard, T. Takano, and R. J. Grant. 2007. Effect of partial replacement of forage neutral detergent fiber with by-product neutral detergent fiber in close-up diets on periparturient performance of dairy cows. J. Dairy Sci. 90:1789-1801.

Dann, H. M., G. A. Varga, and D. E. Putnam. 1999. Improving energy supply to late gestation and early postpartum dairy cows. J. Dairy Sci. 82:1765-1778.

Douglas, G. N., T. R. Overton, H. G. Bateman II, H. M. Dann, and J. K. Drackley. 2006. Prepartal plane of nutrition, regardless of dietary energy source, affects periparturient metabolism and dry matter intake in Holstein cows. J. Dairy Sci. 89:2141-2157.

DuBois, M., K. A. Gilles, J. K. Hamilton, P. A. Rebers, and F. Smith. 1956. Colorimetric method for determination of sugars and related substances. Anal. Chem. 28:350-356.

Ebling, T. L., and L. Kung Jr. 2004. A comparison of processed conventional corn silage to unprocessed and processed brown mid- 
rib corn silage on intake, digestion, and milk production by dairy cows. J. Dairy Sci. 87:2519-2526.

Goering, H. K., and P. J. Van Soest. 1970. Forage fiber analysis. Agric. Handb. 379. US Dept. Agric., Washington, DC.

Goff, J. P. 2006. Major advances in our understanding of nutritional influences on bovine health. J. Dairy Sci. 89:1292-1301.

Goff, J. P., and R. L. Horst. 1997. Effects of the addition of potassium or sodium, but not calcium, to prepartum rations on milk fever in dairy cows. J. Dairy Sci. 80:176-186.

Grummer, R. R., D. G. Mashek, and A. Hayirli. 2004. Dry matter intake and energy balance in the transition period. Vet. Clin. North Am. Food Anim. Pract. 20:447-470.

Hall, M. B. 2009. Determination of starch, including maltooligosaccharides, in animal feeds: Comparison of methods and a method recommended for AOAC collaborative study. J. AOAC Int. 92:42-49.

Hayirli, A., R. R. Grummer, E. V. Nordheim, and P. M. Crump. 2002. Animal and dietary factors affecting feed intake during the prefresh transition period. J. Dairy Sci. 85:3430-3443.

Huzzey, J. M., D. M. Veira, D. M. Weary, and M. A. G. von Keyserlingk. 2007. Prepartum behavior and dry matter intake identify dairy cows at risk for metritis. J. Dairy Sci. 90:3220-3233.

Janovick, N. A., and J. K. Drackley. 2010. Prepartum dietary management of energy intake affects postpartum intake and lactation performance by primiparous and multiparous Holstein cows. J. Dairy Sci. 93:3086-3102.

Johnson, T. R., and D. K. Combs. 1991. Effects of prepartum diet, inert rumen bulk, and dietary polyethylene glycol on dry matter intake of lactating dairy cows. J. Dairy Sci. 74:933-944.

Kononoff, P. J., A. J. Heinrichs, and D. R. Buckmaster. 2003. Modification of the Penn State forage and total mixed ration particle separator and the effects of moisture content. J. Dairy Sci. 86:1858-1863.

Krishnamoorthy, U., T.V. Muscato, C.J. Sniffen, and P.J. Van Soest. 1982. Nitrogen fractions in selected feedstuffs. J. Dairy Sci. $65: 217-225$.
Lammers, B. P., D. R. Buckmaster, and A. J. Heinrichs. 1996. A simple method for the analysis of particle sizes of forage and total mixed rations. J. Dairy Sci. 79:922-928.

NRC. 2001. Nutrient Requirements of Dairy Cattle. 7th rev. ed. Natl. Acad. Press, Washington, DC.

Oba, M., and M. S. Allen. 1999a. Effect of brown midrib 3 mutation in corn silage on dry matter intake and productivity of high yielding dairy cows. J. Dairy Sci. 82:135-142.

Oba, M., and M. S. Allen. 1999b. Evaluation of the importance of the digestibility of neutral detergent fiber from forage: Effects on dry matter intake and milk yield of dairy cows. J. Dairy Sci $82: 589-596$

Oba, M., and M. S. Allen. 2000. Effects of brown midrib 3 mutation in corn silage on productivity of dairy cows fed two concentrations of dietary neutral detergent fiber: 3. Digestibility and microbial efficiency. J. Dairy Sci. 83:1350-1358.

Santos, H., V. Morwira, Z. Wu, and L. D. Satter. 2001. Brown midrib corn silage for transition cows. 2000-2001 Res. Rep. USDA Forage Research Center, Madison, WI

Tyrrell, H. F., and J. T. Reid. 1965. Prediction of the energy value of cow's milk. J. Dairy Sci. 48:1215-1223.

Van Amburgh, M. E., P. J. Van Soest, J. B. Robertson, and W. F. Knaus. 2003. Corn silage neutral detergent fiber: Refining a mathematical approach for in vitro rates of digestion. Pages 99-108 in Proc. Cornell Nutr. Conf. Feed Manuf., East Syracuse, NY. Cornell University, Ithaca, NY

Van Soest, P. J., J. B. Robertson, and B. A. Lewis. 1991. Methods for dietary fiber, neutral detergent fiber and nonstarch polysaccharides in relation to animal nutrition. J. Dairy Sci. 74:3583-3597.

Wildman, E. E., G. M. Jones, P. E. Wagner, R. L. Bowman, H. F. Troutt, and T. N. Lesch. 1982. A dairy cow body condition scoring system and its relationship to selected production characteristics. J. Dairy Sci. 65:495-501. 